\title{
Jak określić czynności liturgiczne prawosławnego duchownego? - podstawy teologiczne i normy językowe*
}

\author{
ks. Marek Lawreszuk \\ Uniwersytet w Białymstoku, Katedra Teologii Prawosławnej, Polska \\ ORCID: 0000-0001-8051-8106 \\ m.lawreszuk@uwb.edu.pl
}

\begin{abstract}
rev. M. Lawreszuk, How to determine the liturgical activities of an Orthodox priest? - theological foundations and language norms,
\end{abstract} Elpis, 22 2020: 113-120.

\begin{abstract}
The article analyzes the problem of unstructured Polish terminology regarding liturgical activities of an Orthodox priest. Presenting the theological assumptions of the priest's ministry, service, dignity or tasks, the article indicates the terms and word connections that correspond to Orthodox ecclesiology.

Streszczenie: Artykuł analizuje problem nieusystematyzowanej polskiej terminologii dotyczącej czynności liturgicznych prawosławnego duchownego. Przedstawiając teologiczne założenia posługi, służby, godności czy zadań kapłana, artykuł wskazuje na terminy i połączenia wyrazowe, które odpowiadają prawosławnej eklezjologii.
\end{abstract}

Keywords: Orthodoxy, terminology, priest, priesthood, liturgical activities

Słowa kluczowe: prawosławie, terminologia, ksiądz, kapłaństwo, czynności liturgiczne

Terminologia chrześcijańska zna wiele określeń osoby, która organizuje i prowadzi do relacji ludzi z Bogiem. Taka osoba może być kapłanem, duchownym, starszym, przewodnikiem. Szczegółowa charakterystyka rozwija te podstawowe określenia wymieniając stopnie kapłańskie, ograniczając lub poszerzając definicję technicznymi określeniami biskup, prezbiter, papież, patriarcha, diakon, arcykaptan, kapelan. Terminologia prawosławna wykorzystuje zarówno te nazwy, które zrodziły się na gruncie chrześcijańskim, jak i wprowadza do słownictwa inne terminy $\mathrm{z}$ tradycji judaistycznej lub dziedzictwa innych religii czy instytucji społecznych, przypisując im jednak najczęściej bardziej precyzyjne znaczenia. Niemniej jednak każde $\mathrm{z}$ tych określeń $\mathrm{w}$ swej etymologii i historii nieco inaczej charakteryzuje konkretną osobę pełniącą konkretną funkcję. Ich zabarwienie i kontekst mogą sugerować zarówno pokorę i postawę służebną, jak i przewodnictwo lub dominację ponad innymi ludźmi. $Z$ tego powodu terminologia określająca osoby odpowiedzialne za prowadzenie nabożeństw w Cerkwi prawosławnej została precyzyjnie uporządkowana, pozostając jednak pod nieustannym wpływem wciąż zmieniającego się języka (Ławreszuk, 2019, s. 15-16).

W niniejszym opracowaniu terminologia ta, tuż za fundamentem zasad teologicznych, stanie się jednym z filarów pomocnych w ukazaniu roli prawosławnego duchownego we wspólnocie liturgicznej. Jaka jest liturgiczna rola duchownego? Czy jest pasterzem, władcą, najemnikiem, niewolnikiem czy sługą Boga lub wspólnoty?

\footnotetext{
* Publikacja finansowana w ramach programu Ministra Nauki i Szkolnictwa Wyższego pod nazwą „Narodowy Program Rozwoju Humanistyki" w latach 2017-2022, nr projektu 0083/NPRH5/H11/84/2017.
}

Finalnym celem niniejszego artykułu będzie próba zdefiniowania pełnionych przez duchownego funkcji liturgicznych, które mogą i powinny być stosowane w polskiej terminologii prawosławnej.

\section{Terminologia przedchrześcijańska, niechrześcijańska i chrześcijańska}

$\mathrm{W}$ różnych systemach wierzeń znajdujemy terminy określające osobę organizującą życie religijne. W religii starotestamentowej, podobnie jak w wielu religiach niechrześcijańskich i to zarówno $\mathrm{w}$ pierwotnych wierzeniach, kultach pogańskich, jak i dużych systemach religijnych, osobę taką określamy terminem kapłan.

W polskiej terminologii termin ten związany jest zarówno ze Starym Testamentem i religią judaistyczną, jak i pogańskimi kultami. Na bazie mitologii słowiańskiej pojawia się co prawda jeszcze termin żerca, który odnosi się do religii pierwotnych i kultu pogańskiego, jednak nie jest on upowszechniony (Szyjewski, 2004, s. 153).

Żerca ma swój historyczny polski odpowiednik i jest nim ofiarnik (Kapłan w: Podręczna Encyklopedya Kościelna, t. 19, s. 311). Etymologia terminu żerca nawiązuje do słowiańskiego zhreca, czyli tego, który składa ofiarę (cs. zhertva). Jego definicja podkreśla funkcję ,pośrednika między bogami i ludźmi” i ogranicza jego wykorzystanie jedynie do „kultu przodków” tj. do religii pierwotnych i politeistycznych (Zhrecy, w: Jenciklopedicheskij slovar' Brokgauza i Efrona, 1894).

Kapłan rozumiany jest $\mathrm{w}$ języku polskim zarówno jako „osoba wykonująca czynności kultowe” w religiach 
pierwotnych lub politeistycznych, jak i osoba realizująca podobne funkcje w religii chrześcijańskiej (Kaptan w: Słownik języka polskiego PWN, 2019). „Podręczna Encyklopedya Kościelna” z 1910 roku rozwija ten termin wyłącznie w kontekście chrześcijańskim, utożsamiając go $\mathrm{z}$ łacińskim sacerdos i greckim jereos (Kapłan w: Podręczna Encyklopedya Kościelna, t. 19, s. 311). Ponadto wskazuje na alternatywny termin ofiarnik wraz z wariantem ofiarownik, stanowiący synonim kapłana. Encyklopedia przytacza także opinię, iż ofiarnik jest właściwszym odpowiednikiem greckiego jereos aniżeli zapożyczony z łacińskiego cappellanus i spolszczony termin kapłan (Kaptan w: Podręczna Encyklopedya Kościelna, t. 19, s. 311).

Dziedzictwo Starego Testamentu często wykorzystuje termin kapłan w znaczeniu sługi Boga Najwyższego. Pierwotnie mówi o kapłanach pogańskich. Ich funkcja była głównie ofiarnicza. Sprawowali kult w świątyniach, przekazywali treść wyroczni lub proroctw, składali ofiary i stali na straży przestrzegania zasad i norm religijnych. Kapłaństwo lewickie pojawia się znacznie później. Kapłanem był biblijny Melchisedek, kapłanami są również potomkowie Abrahama, ród kogenów, którzy składali ofiary w Świątyni Jerozolimskiej (Ławreszuk, 2014, s. 48). W tradycji judaistycznej termin ten oznacza tego, który składa ofiary. Stary Testament mówi jednak także o najważniejszym z kapłanów, którego określa jako „najwyższego kapłana”, „głównego kapłana” czy „namaszczonego kapłana”, a który najczęściej bywa nazywany arcykapłanem. Pierwszym biblijnym arcykapłanem był Aaron, który dał początek wyodrębnieniu z kapłańskiego rodu kogenów jednego, przewodniczącego, który wkrótce (ok. 850 r. p.n.e.) został dodatkowo urzędnikiem państwowym $\mathrm{w}$ funkcji sędziego apelacyjnego $\mathrm{w}$ sprawach religijnych, a później przewodniczącym Sanhedrynu (ok. 200 r. p.n.e.). Arcykapłan łączył funkcje religijne i polityczne do 37 r. p.n.e. kiedy to królem Judei został obrany Herod Wielki.

Tradycja chrześcijańska wskazuje na dwa znaczenia terminu arcykaptan. Pierwsze, najbardziej rozpowszechnione wiąże go z Jezusem Chrystusem. O tym chrześcijańskim znaczeniu arcykapłana pisze ap. Paweł (Hbr 2,17). O drugim, starym i mało znanym mówi zabytek II wieku „Didache”, w którym arcykapłanami nazwani zostali wczesnochrześcijańscy prorocy (Ławreszuk, 2014, s. 64).

Problemem chrześcijańskiej adaptacji terminu kapłan staje się funkcja, która została mu przypisana, tzn. funkcja ofiarnika, sługi kultu. Widoczne jest to już w pierwszych dniach Nowego Przymierza, kiedy Jezus Chrystus nauczający, uzdrawiający i czyniący cuda, jest określany w rozmaity sposób przez swoich uczniów. Jest dla nich Mistrzem, Prorokiem, Synem Dawidowym, Mesjaszem, Zbawicielem, Panem, Synem Bożym, ale ... nie nazywają go ani kapłanem, ani arcykapłanem. „Nieobecność tych terminów wskazuje całkiem jasno, że Kościół pierwotny był w pełni świadom pojawienia się czegoś całkiem nowego i dlatego początkowo nie mógł tego wyrazić za pomocą istniejących dotychczas określeń. Konieczne stało się więc opracowanie na nowo zasadniczych pojęć dotyczących kapłaństwa, tak aby było możliwe zastosowanie ich w odniesieniu do tajemnicy Chrystusa" (Vanhoye, 2015).

\section{Starotestamentowy kaplan a Jezus Chrystus}

Zbawcze dzieło Jezusa Chrystusa nie koncentruje się na składaniu ofiary. Modlitwa wieczerzy paschalnej opisana w Ewangelii ukazuje co prawda Mesjasza jako tego, który przewodniczy modlitwie, a więc w oparciu o starotestamentowe rozumienie jest dla zgromadzonych kapłanem, lecz Mistyczna Wieczerza nie staje się obrazem złożonej rytualnej i wskazanej przepisami ofiary, lecz nową ofiarą, zaś sam Chrystus jest ukazany nie jako „celebrujący”, lecz ,jak ten, kto służy” (Łk 22,27) swoim uczniom. W czym zauważalna jest różnica pomiędzy starotestamentową ofiarą a ofiarą Zbawiciela? Zwrócił na to uwagę apostoł Paweł w Liście do Hebrajczyków: starotestamentowy kapłan, ustanowiony dla ludzi, wchodził do świątyni „z cudzą krwią” (Hbr 9,25) i nie ofiarowywał Bogu niczego osobistego, albowiem nie był zdolny ani godny, aby ofiarować samego siebie (Vanhoye, 2015). Składał ofiary najpierw za swoje grzechy, a później za grzechy narodu wybranego. Ofiara Jezusa Chrystusa była ofiarą osobistą, Jego Ciałem i Jego Krwią (por. Hbr 9,14). Apostoł Paweł podkreśla tę różnicę słowami: złożył „ofiarę z samego siebie” (Hbr 9,26) i wszedł do świątyni „nie przez krew kozłów i cielców, lecz przez własną krew" (Hbr 9,12). Kapłaństwo Chrystusa niesie więc inną treść aniżeli termin starotestamentowy (Bogacz, 2007, s. 25). Chrystus jest pośrednikiem, tym który sam siebie składa w ofierze. Częściej więc jest określany jako właśnie ta doskonała ofiara, na co wskazuje przyjęte w Nowym Testamencie określenie Zbawiciela jako Baranka Bożego. W przeciwieństwie do wciąż odnawialnej ofiary starotestamentowych kapłanów Jezus Chrystus jedynie raz składa ofiarę, która była doskonała i przez którą wszyscy mogą być zbawieni.

Ewangelista Jan podkreśla także, że kapłaństwo Chrystusa i wypływające stąd inne, nowe znaczenie kapłana, definiuje sie poprzez wskazane przez Zbawiciela zadanie wierzących w niego ludzi - oddawanie Bogu czci „,w Duchu i prawdzie" (J 4,23). Stąd przykazanie składania ofiar przebłagania, dziękczynienia i próśb zostają w zbawczym dziele Chrystusa przewartościowane. Rodzi się w ten sposób nowe, chrześcijańskie rozumienie terminu kapłan, ale również wskazane są nowe zadania, które stają przed chrześcijańskimi kapłanami i wspólnotą wiernych.

\section{Tradycja wczesnochrześcijańska}

Tradycja wczesnochrześcijańska nie wykorzystywała terminu kapłan. Zamiast tego opisywała swoich nauczycieli i przewodników terminem starszy, nadzorca, opiekun. Z tych greckich terminów rodzą się specjalistyczne 
określenia osób duchownych. Pierwszymi nauczycielami i głosicielami Nowego Przymierza stają się apostolowie. Kerygma apostolska jest kontynuowana przez ich uczniów, powołanych do dalszego głoszenia Ewangelii. Byli oni określani jako starsi, z greckiego ijereos. Na przełomie I i II wieku nazywano tak równie często biskupów, jak i prezbiterów. Na początku II wieku dość jednoznacznie zaczęto rozróżniać opiekunów lub nadzorców wspólnot chrześcijańskich i ich określano biskupami, natomiast nauczycieli i przewodniczących konkretnych małych wspólnot zaczęto określać starszymi, tj. prezbiterami.

Jeśli w okresie wczesnochrześcijańskim spróbować odnaleźć termin, który ogólnie opisywał funkcje biskupów, prezbiterów, ojców apostolskich, mężów apostolskich, misjonarzy, nauczycieli czy proroków, to terminem takim był starszy. Nie było to novum w środowisku wywodzącym się z religii starotestamentowej. Judaistyczna organizacja lokalnych wspólnot (rodzinnych, wiejskich czy miejskich) znała bowiem praktykę starszeństwa, jako normę, która organizowała domowe czy lokalne życie modlitewne. To starszy przewodniczył modlitwie domowej, jak również pełnił funkcję prowadzącego sobotnie lub paschalne modlitewne wieczerze. Starszy nie oznaczał jedynie najstarszej osoby. Praktyka sprawowania modlitewnej wieczerzy żydowskiej mówiła, że prowadzić ją powinien ,ojciec rodziny, rabin bądź dostojny gość” (Ławreszuk, 2014, s. 42-43). Wykorzystanie tego terminu w praktyce wczesnochrześcijańskiej pozwala odkryć drugie znaczenie chrześcijańskiego kapłana, jako nie tego, który jedynie składa ofiary, ale też i tego, który naucza i który wspólnie ze swoimi bliskimi się modli i przewodniczy tej modlitwie.

Kiedy po wiekach polska terminologia łączy dwa znaczenia $\mathrm{w}$ jednym terminie kaptan, musi ono być rozumiane przez pryzmat chrześcijańskiej tradycji. W niej kaptan jest nie tylko tym, który składa ofiary. To znaczenie ofiarnicze Świątyni Jerozolimskiej i tradycji starotestamentowej zostało już wypełnione przez ofiarę Jezusa Chrystusa. Chrześcijański kapłan jest raczej tym, który przewodniczy wspólnej modlitwie, a jego działania ofiarnicze opierają się na „oddawaniu czci”, prowadzeniu rozumianemu jako kerygmatyczne nauczanie, ewangelizacja, misyjność, ale i „stanie przed współbraćmi” (cs. predstojanije) i angażowanie ich do wspólnej modlitwy, symbolicznych czynów i obrzędów.

Z tego zróżnicowania rodzi się niechęć przed nadmiernym wykorzystywaniem określenia kapłan. Stąd w chrześcijańskiej terminologii biskup, prezbiter czy diakon stają się często abba, ojcem (z gr. papas, stąd również papież), zaś wierni stają się braćmi i siostrami (Lawreszuk, 2019, s. 16-18). W terminologii prawosławnej zdecydowanie częściej wykorzystywane są terminy duchowny, duchowieństwo, aniżeli kapłan, kapłani czy wskazujące na hierarchiczność i jurydyczność określenie stan kapłański. Nie mniej jednak są to synonimy określające ogólnie wszystkich tych, którzy zostali powołani w Cerkwi do nauczania Słowa Bożego i dokonywania czynności liturgicznych.

\section{Reguły liturgiczne i teologia liturgiczna}

Opierając się na starotestamentowych zadaniach kapłana i nowotestamentowej, odmienionej funkcji duchownego powinniśmy przeanalizować istniejące $\mathrm{w}$ języku polskim połączenia wyrazowe wskazujące na liturgiczne zadania duchownego. W tej części spróbujemy również zdefiniować i wskazać na różnice w prawosławnej terminologii dotyczącej duchownych ich funkcji i obowiązków.

Liturgiczne działania duchownych są określane przy wykorzystaniu wielu terminów. W polskiej terminologii prawosławnej, w ramach prowadzonych badań nad „Słownikiem polskiej terminologii prawosławnej” zespół grantowy przeanalizował istniejące współczesne źródła i wyodrębnił z nich m.in. połączenia wyrazowe dotyczące liturgicznych działan duchownego. Lista źródeł i metodologia pracy została opisana przez J. Charkiewicza w roku 2018 (Charkiewicz, 2018, s. 181-186). Wśród ponad 4000 ekscerpowanych terminów w kontekście czynności liturgicznych duchownego możemy mówić o: sprawowaniu (w połączeniach sprawować nabożeństwo, misterium, obrzęd, liturgię), odprawianiu, stużeniu (w połączeniach służyć nabożeństwo, misterium, obrzęd, liturgię), celebracji (w połączeniach celebrować nabożeństwo, misterium, obrzęd, liturgię), a także o koncelebrowaniu, koncelebracji, wspótsprawowaniu, wspótstużeniu i asyście duchownych w nabożeństwie.

Wyżej wskazane terminy możemy uporządkować w dwie grupy. Pierwszą, która gromadzi określenia czynności liturgicznych pojedynczego duchownego oraz drugą, która czynności te opisuje w sytuacji, kiedy w nabożeństwie uczestniczy wielu duchownych.

Pierwsza grupa, jak wynika z łączliwości, opisuje działanie duchownego. Terminy te funkcjonują jednak również w mowie potocznej, stąd nierzadko przyjmują plagialne zabarwienie.

Rola duchownego w nabożeństwie nie może zostać opisana w kontekście starotestamentowego kapłana. Nie jest on tylko i wyłącznie ofiarnikiem. Nie składa ofiary przebłagania. Stanowi cząstkę mistycznego Ciała Chrystusa, za które swoją doskonałą ofiarę złożył Zbawiciel. Prawosławna teologia nie mówi o liturgii jako o ofierze odkupienia składanej tu i teraz na „wspomnienie” ofiary Chrystusa. Prawosławna liturgia nie jest wspomnieniem, lecz stanowi realną Mistyczną Wieczerzę (Ławreszuk, 2014, s. 123), ponadczasowym obcowaniem z Bogiem. Oddawanie czci Bogu w duchu i prawdzie wymyka się z przestrzeni konkretnej świątyni i ucieka przed granicami czasu. Nie dotyczy też wyłącznie tych, którzy gromadzą się o określonej godzinie w określonym miejscu, lecz staje się tajemnym współuczestnictwem w Bożej modlitwie (Golosov, 1886, s. 41-42). Jezus Chrystus obiecał być z wierzącymi tam, gdzie ,dwoje lub troje gromadzi się w moje imię" (Mt 18,20) i ,przebywać z nimi we wszystkie dni aż do końca świata" (Mt 28,20). 
Duchowny nie jest tylko ofiarnikiem, lecz także tym, który otrzymał prawo przynoszenia miłej Bogu ofiary. Ofiarą tą nie jest wyłącznie antytyp Ciała i Krwi Chrystusa. Modlitwy Boskiej Liturgii św. Jana Chryzostoma i Bazylego Wielkiego mówią o duchownym, który składa „bezkrwawą ofiarę”" (Boska Liturgia świętego ojca naszego Jana Chryzostoma, 2001, s. 47). W modlitwie proskomidii Boskiej Liturgii św. Jana Chryzostoma ofiara ta jest nazywana „ofiarą duchową" (Boska Liturgia świętego ojca naszego Jana Chryzostoma, 2001, s. 12). Liturgiczna ofiara ukazuje teologiczną antynomię ,....w niej Sam Chrystus Zbawiciel staje się zarówno Arcykapłanem, który przynosi ofiarę, jak i Ofiarą, którą jest przynoszona za grzechy świata" (Kern, 2006, s. 261) (Besobrasoff, 1939, s. 105114). Liturgia, zdaniem archim. Cypriana, to ponadczasowe powtórzenie ofiary Chrystusa bez krwawej ofiary. Nie jest to ofiara ziemskiego Ciała Chrystusa, zdradzonego w Getsemani, cierpiącego na Golgocie czy pogrzebanego w grobie, lecz Ciała wysławionego po Zmartwychwstaniu, Wniebowstąpieniu i zjednoczeniu ze Świętym Duchem. Ciało to jest ,nierozdzielne od Krwi, albowiem rozdzielone w Grobie stało się zjednoczonym w przemienionym Ciele Zmartwychwstałego" (Kern, 2006, s. 263).

Prawosławna teologia podkreśla więc złożenie duchowej, bezkrwawej ofiary, która jednak wykracza poza czas i przestrzeń i staje się ofiarą „za wszystkich i za wszystko” (Soborowa Komisja Redakcyjna, Pańkowski, 2011, s. 64).

W modlitwie wiernych Boskiej Liturgii św. Jana Chryzostoma duchowny wygłasza prośbę, która podkreśla, że ofiara składana jest przez wspólnotę, przez tych, którzy „modlą się z nami” i z „miłością służą Tobie”: Znowu $i$ wielokroć przypadamy do Ciebie i błagamy Cię, Dobry i Miłujacy człowieka, abyś wejrzawszy na błaganie nasze, oczyścit nasze dusze i ciała z wszelkiej zmazy ciała i ducha, i pozwolit nam stanać przed świętym Twoim oltarzem niewinnie i bez osądzenia. Daruj zaś, Boże, i tym, którzy modla się z nami, wzrastanie $w$ życiu, wierze i zrozumieniu duchowym. Pozwól im zawsze z bojaźniq i miłościa stużyć Tobie, aby niewinnie i bez osadzenia przyjać święte Twoje Tajemnice i być godnymi niebiańskiego Twego królestwa (Soborowa Komisja Redakcyjna, Pańkowski, 2011, s. 5152). Wraz z duchownym również i wspólnota wspólsłuży w dokonywaniu eucharystycznego ofiarowania, które realizuje się w złożeniu i ofiarowaniu chleba i wina. Duchowny „nie przedstawia siebie w oderwaniu od wspólnoty wiernych, lecz wręcz przeciwnie, podkreśla jednomyślność i wspólne sprawowanie Eucharystii" (Kern, 2006, s. 168-169).

Przemiana ofiarowanych darów dokonywana jest już jednak nie przez duchownego, lecz laską Świętego Ducha. Epikleza to przywołanie i prośba skierowana do Boga o przemianę przedłożonych darów. Przyniesienie i ofiarowanie nie kończy liturgii, która staje się mistyczną ofiarą poprzez Boże działanie. Działanie to, przemieniające chleb i wino w Ciało i Krew Zbawiciela, nie dokonuje się w oparciu o wygłoszenie „formuły sakramentalnej”, tak naprawdę obcej prawosławnej teologii, lecz poprzez całościowe ujęcie modlitwy eucharystycznej, z duchowym kontek- stem wszystkich wygłaszanych modlitw i czynności liturgicznych. Dlatego prawosławny duchowny nie jest, jak to określa rzymskokatolicka doktryna, „minister sacramenti” ani tym bardziej „Stellvertreter Christi” (niem. zastępcą Chrystusa), lecz wygłaszając słowa Zbawiciela wypowiedziane na Wieczerzy Mistycznej dokonuje anamnezy, czyli modlitewnego wspomnienia zbawiennego dzieła Samego Boga (Kern, 2006, s. 213-214). Chrystus jest realnie obecny w liturgii i prawosławie odrzuca nauczanie o obecności w obrazie chleba i wina (łac. sub pane, cum pane, in pane) (Kern, 2006, s. 205). Każda Boska Liturgia to nowe Wcielenie i nowe powtórzenie Golgoty, a więc i wspomnienie (anamneza) cierpień Boga (por. 1Kor 11,26), ale i wspomnienie przyszłości (tj. Powtórnego Przyjścia). Przejście od anamnezy do epiklezy wskazuje, że rolą wspólnoty pod przewodnictwem duchownego jest wspomnienie zbawczego dzieła i prośba o zstąpienie Świętego Ducha na dary. Okazanie Bogu darów również dokonywane jest przez wspólnotę. Prezbiter lub biskup wygłaszają słowa, zaś diakon wznosi (z gr. anafora) przedłożone dary, co ukazuje na wspólne działanie.

Duchowny (biskup, prezbiter) w trakcie Eucharystii jest, zgodnie ze słowami św. Maksyma Wyznawcy, obra-

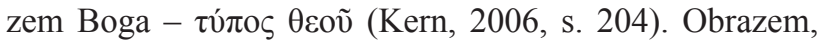
lecz nie antytypem. Nie może przyjąć na siebie roli, wskazywanej przez Kościół rzymskokatolicki, opierającej się na wygłoszeniu ,formuły sakramentalnej” w roli uosobienia Chrystusa (in persona Christi). W tej roli duchownego epikleza nie byłaby konieczna. Jeśli tradycja rzymskokatolicka dopuszcza uświęcające działanie Świętego Ducha, to Duch jest jedynie silleiturgos tj. Wspótstużacym (niem. Mitconsekrator) (Naegle, 1900, s. 144). Działanie duchownego to prośba skierowana do Boga: ,ześlij Ducha Twego Świętego... i uczyń... przemieniając Duchem Twoim Świętym" (Soborowa Komisja Redakcyjna, Pańkowski, 2011, s. 65-66). P. Trembelas potwierdza to słowami: „Biskup lub prezbiter nie jest panem lub samodzielnym realizatorem misteriów, lecz jedynie nieodzownym instrumentem, z pomocą którego misterium niewidzialnie dokonywane jest przez «wielkiego arcykapłana» Jezusa Chrystusa, który nierozdzielnie przebywa z Cerkwią jako ze swoim mistycznym Ciałem i je uświęca" (za: Gotc, 2014, s. 236-238).

\section{Terminologia określająca duchownego i jego czynności liturgiczne}

W kontekście ofiary eucharystycznej i innych czynności liturgicznych duchowny jest, i może być określony jako:

- sluga, który składa ofiarę i wygłasza modlitewne prośby, błagania i dziękczynienia. W cerkiewnosłowiańskiej terminologii funkcjonują terminy cerkovnosluzhitel'oraz svjashchennosluzhitel'. Szczególnie ten ostatni charakteryzuje duchownego jako tego, który 
stuży świętości. Jest to termin dwuznaczny. W źródłach teologicznych stanowi synonim duchownego i jest hiperonimem diakona, prezbitera i biskupa. W źródłach liturgicznych a szczególnie w kontekście teologii liturgicznej podkreśla służebną rolę w mistycznym (sakramentalnym) działaniu.

- sprawujący nabożeństwo;

- przewodniczący nabożeństwu. Termin wskazuje na pozycję duchownego we wspólnocie i oznacza tego, który stoi przed wiernymi i z nimi oraz $\mathrm{w}$ ich imieniu wygłasza słowa modlitw oraz dokonuje czynności liturgicznych. Cerkiewnosłowiański termin predstojatiel podkreśla „stanie przed”, które może być rozumiane jeszcze szerzej, nie tylko jako reprezentowanie głosu wiernych i fizyczne stanie przed nimi i bliżej ołtarza, lecz również jako „stanie przed Bogiem”, tj. wejście do prezbiterium i złożenia ofiary Bogu. Polski termin akcentuje jedynie to pierwsze rozumienie „reprezentanta-przedstawiciela”, przy czym nie deprecjonuje w żaden sposób roli i funkcji zgromadzonych wiernych.

- celebrujący nabożeństwo. Termin ten stanowi synonim sprawującego. Jego wykorzystanie w języku polskim nie jest jednak rozpowszechnione ze względu na wieloznaczność. Chociaż określa on przede wszystkim kogoś, kto czegoś dokonuje, to jednocześnie kryje w sobie pewien element wartościujący. W swej definicji „celebracja” podkreśla dokonywanie sakralnych czynności w określony sposób: uroczyście, z namaszczeniem, nawet pompatycznie. W XX wieku pojawia się nawet termin celebryta, który wykorzystuje już całkowicie wcześniejsze plagialne znaczenie. W kontekście terminologii prawosławnej celebrujący może więc być rozumiany dwojako i oznaczać: duchownego sprawującego nabożeństwo lub duchownego, który w określony (uroczysty, podniosły, pompatyczny, świąteczny, niecodzienny) sposób sprawuje nabożeństwo. Z tego względu wykorzystanie tego terminu powinno być ograniczane do kontekstu oficjalnych wypowiedzi, które nie budzą dwuznaczności, jako synonim głównego i podstawowego terminu: sprawuja$c y$. Polska terminologia prawosławna, na co wskazują ekscerpowane źródła (Charkiewicz, 2018, s. 181-186), nie zaadoptowała wariantu tego terminu w postaci $c e-$ lebransa.

Działania liturgiczne prawosławnego duchownego, opierając się na wyżej przedstawionych terminach, mogą być i są w języku polskim określane jako:

- sprawowanie nabożeństwa, jak również sprawowanie ofiary, Boskiej Liturgii, Eucharystii, ofiary eucharystycznej;

- stużenie Bogu i dalej stużenie Bogu i ludziom. Termin pochodzi od służby, w języku greckim nazywanej latria. Latria stanowi precyzyjne określenie oddawania czci Bogu, i tylko jemu. W oparciu o ten termin rodzą się dalej terminy nabożeństwo - w języku greckim dosłownie stużba Boża (lub służba Bogu). Podobnie cerkiewnosłowiański odpowiednik nabożeństwa, czyli bogosluzhenije podkreśla aspekt służby Bogu. Terminologia cerkiewnosłowiańska rozbudowała pierwotny termin do szeregu stałych połączeń wyrazowych, w tym m.in. do formy sluzhit' bozhestvennuju sluzhbu lub sluzhit' bogosluzhenije. Stąd, przy rozwiniętych cerkiewnosłowiańskich określeniach nabożeństw rozpowszechniło się połączenie: sluzhit' liturgiju itp. W kontekście stużby Bogu i ludziom realizowanej w liturgicznych czynnościach, opierając się na terminologii cerkiewnosłowiańskiej, w języku polskim pojawiło się potoczne określenie stużenia nabożeństwa, tj. dokonywania czynności liturgicznych z perspektywy sługi Boga i wspólnoty. Służebna rola duchownego wyraża się w prośbie anafory - przedłożenia Bogu darów w imieniu swoim i wspólnoty oraz prośbie epiklezy - skierowanej do Boga Ojca i oczekującej na działanie Świętego Ducha. Preferowana łączliwość tego terminu to stużenie Bogu, która jednak nie ogranicza rozumienia wyłącznie, czy głównie, do czynności liturgicznych. $Z$ tego względu nie może być traktowane jako pełny i jednoznaczny synonim sprawowania nabożeństwa. Połączenie wyrazowe stużenie nabożeństwa ukazuje z kolei niespotykaną $\mathrm{w}$ języku polskim łączliwość $\mathrm{z}$ biernikiem odpowiadając na pytania: kogo? co? (zamiast naturalnie oczekiwanej łączliwości z celownikiem: służyć komu czemu Bogu, ludziom, Cerkwi, światu itd.). Połączenie z biernikiem: służyć co? - nabożeństwo, Boską Liturgię, Eucharystię, ofiarę podkreśla dokonywanie czynności liturgicznej, w której duchowny pełni funkcję służebną przed Bogiem (i/lub wspólnotą). Ta charakterystyczna cecha prawosławnej teologii liturgicznej nie powinna zostać utracona. $Z$ tego względu, pomimo uzusu łączliwości, postuluje się zachowanie tego terminu jako potocznego synonimu sprawowania. Kolejnym argumentem za pozostawienie tego terminu wyłącznie w charakterze dopuszczalnego i potocznego jest jego wykorzystanie $\mathrm{w}$ terminologii rzymskokatolickiej, w której jest on ograniczony wyłącznie do postugi ministrantów. Próba rozpowszechnienia terminu w polskiej terminologii prawosławnej mogłaby prowadzić do braku czytelności przekazu i wieloznaczności.

- przewodniczenie nabożeństwu, jak również przewodniczenie modlitwie, Boskiej Liturgii. Najczęściej termin ten wykorzystywany jest w opisach nabożeństw, w których czynności liturgicznych dokonuje biskup lub znany duchowny. Kontekst wypowiedzi pozycjonuje wykorzystanie tego terminu $\mathrm{w}$ wypowiedziach o charakterze sprawozdawczym, dziennikarskim, reporterskim. Może on być również wykorzystywany w celu skonkretyzowania informacji o duchownym w sytuacji, kiedy w nabożeństwie uczestniczy wielu duchownych. Wówczas przewodniczenie uzyskuje kolejne znaczenie - wskazanie tego spośród duchownych (biskupa lub prezbitera), który stoi „przed” pozostałymi duchownymi, i który dokonuje główne lub wszystkie czynności liturgiczne. 
- celebrowanie nabożeństwa lub celebra, celebracja nabożeństwa, podobnie jak termin celebrujacy podporządkowany jest częściej obecnemu określeniu sprawowanie. Argumentem na rzecz marginalizacji tego terminu jest jego wieloznaczność.

- odprawianie nabożeństwa. Ten wieloznaczny termin, w jednym ze znaczeń wskazuje na dokonywanie pewnych czynności według ustalonego wcześniej porządku. Jest on często wykorzystywany w kontekście opisu czynności liturgicznych. Należy jednak podkreślić jego funkcjonalne, techniczne zabarwienie. W kontekście teologicznym termin ten nie mówi o przeżywaniu, nastawieniu czy intencjach, a przede wszystkim o dokonaniu (realizacji) określonego zadania. $\mathrm{Z}$ tego względu jego wykorzystanie jako synonimu sprawowania jest dopuszczalne i rzadkie.

Zakładając rozumienie nabożeństwa jako służby Bogu dokonywanej nie tylko przez duchownego, lecz także przez wspólnotę wiernych, należy stwierdzić, że przytoczone wyżej terminy: sprawowanie, stużenie, celebracja i odprawianie koncentrują się wyłącznie na charakterystyce działań duchownego bądź opisują nabożeństwo. Brak jest zarejestrowanej łączliwości tych terminów, która mogłaby zostać wykorzystana dla określenia funkcji wiernych. Zaangażowanie wspólnoty jest $\mathrm{w}$ zasadzie określane jednym neutralnym terminem uczestnictwo. Z perspektywy prawosławnej teologii liturgicznej jest to właściwe określenie.

\section{Terminy wykorzystywane na określenie czynności liturgicznych wielu duchownych}

Ostatnim, lecz jednym z ważniejszych aspektów opisywania czynności liturgicznych prawosławnego duchownego są sytuacje, kiedy wspólnota wiernych gromadzi się na nabożeństwie, w którym aktywnie uczestniczy kilku duchownych. Mogą to być prezbiterzy, prezbiterzy i diakoni, czy biskup, prezbiterzy i diakoni.

Opierając się na przedstawionych wyżej terminach i wynikach ekscerpcji terminów z polskojęzycznych źródeł (Charkiewicz, 2018, s. 181-186), czynności te są opisywane z wykorzystaniem terminów sprawowanie, celebrowanie (celebracja), odprawianie, stużenie. Pojawiają się również dotychczas nieanalizowane określenia: koncelebracja, asysta, wspótsprawowanie, wspótstużenie.

Pozycjonowanie tych terminów musi zostać poprzedzone wyjaśnieniem funkcji wielu duchownych w nabożeństwie. Zasadnicze pytanie jest następujące: czy nabożeństwo (liturgia i inne nabożeństwa) i czynności liturgiczne są dokonywane wyłącznie przez jednego $\mathrm{z}$ duchownych? Teologiczna analiza przeprowadzona wyżej wskazuje, że odpowiedź musi być zgodna z następującymi normami:

- duchowny nie jest starotestamentowym żerca lub ofiarnikiem, który może sam składać ofiarę bez obecności i aktywnego udziału wiernych;
- duchowny jest tym, który wygłasza modlitwy w imieniu swoim i zgromadzonej wspólnoty oraz tych, za których wszyscy wspólnie się modlą;

- duchowny jest tym, który przygotowuje, przynosi i składa ofiarę wspólnoty, a w modlitwie kanonu eucharystycznego, stanowiąc obraz Chrystusa, składa dziękczynienia, wspomina zbawcze dzieło, wznosi dary i w części epikletycznej prosi o zesłanie Świętego Ducha i przemianę darów;

- wierni są wspótbraćmi, którzy wspótstużą Bogu w czasie nabożeństwa.

Powyższe normy akcentują wspólnotowość nabożeństwa, które łączy nie tylko Cerkiew widzialną i niewidzialną, lecz również duchownego oraz wiernych. Prawosławna tradycja liturgiczna zna praktykę uczestniczenia w nabożeństwie wielu duchownych. Charakter nabożeństwa odzwierciedla ustawienie się duchownych wokół ołtarza prezbiterium (lub w innych miejscach), gdzie centralne miejsce przed wschodnią stroną ołtarza zajmuje jeden z duchownych, zaś pozostali ustawiają się po północnej i południowej stronie ołtarza. To ustawienie wyodrębnia jednego spośród wielu duchownych (jednego z biskupów - w przypadku ich obecności, lub jednego z prezbiterów w sytuacji, kiedy w nabożeństwie nie uczestniczy biskup). Duchowny ten, podobnie jak w analizowanej wyżej sytuacji, określany jest najczęściej jako predstojatiel, czyli przewodniczacy nabożeństwu.

Słowiańska tradycja mówi o sosluzhenii lub o sobornom sluzhenii (Kern, 2006, s. 181). W języku polskim pierwszy termin może być przestawiany jako wspótsprawowanie lub potocznie wspótstużenie. Przedstawione połączenie nie jest już jednak jednoznacznie ugruntowane w języku polskim i opiera się na opisowych sformułowaniach wspólne sprawowanie, wspólna celebracja, soborowe sprawowanie, które oprócz tego są rzadko rejestrowane. Z perspektywy teologii liturgicznej a szczególnie w przypadku charakterystyki liturgii, terminy sosluzhenie oraz sobornoe sluzhenie są pełnymi synonimami. Każde wspótsprawowanie jest więc soborowym albo wspólnym. $\mathrm{Z}$ tego względu, a także $\mathrm{z}$ powodu braku ugruntowanych połączeń, rozsądnym wydaje się skupienie na proponowaniu jednego wiodącego terminu.

Jeśli aktywne uczestnictwo wielu duchownych określimy jako wspótsprawowanie (cs. sosluzhenie) lub soborowe sprawowanie (cs. sobornoe sluzhenie), będzie to zgodne z teologiczną zasadą prawosławnej liturgiki.

Liturgia i każde nabożeństwo to aktywne działanie wspólnoty wiary, w której każdy element współpracuje $\mathrm{w}$ jednym celu i bez rozerwania z pozostałymi. Wierni uczestniczą w modlitwie duchownego, w określonych momentach wspólnie odpowiadają na jego słowa, angażują się postawą, intencją i uczuciami. Duchowny (biskup, prezbiter) przewodniczący nabożeństwu, sprawuje je wspierany obecnością i zaangażowaniem wiernych. W imieniu całej wspólnoty składa ofiarę eucharystyczną. W imieniu wszystkich prosi o zstąpienie Świętego Ducha. On jeden jest przewodniczacym nabożeństwa, lecz wspierają go swym zaangażowaniem wierni i duchowni. $\mathrm{W}$ jakim stop- 
niu? Stopień zaangażowania jest różny. Wierni przynoszą ofiarę, tj. dawniej chleb i wino, obecnie symbol tej ofiary w postaci świec. Duchowni wspierają przewodniczacego aktywnie uczestnicząc $w$ nabożeństwie, przygotowując przyniesione dary, czytając poszczególne modlitwy i błogosławieństwa, uczestnicząc w procesjach i angażując się w czynności liturgiczne przewodniczacego. Jeśli odwołamy się do istoty misterium Eucharystii realizującego się w działaniu Świętego Ducha przywoływanego w modlitwie epiklezy, wtedy jednoznacznie powinniśmy wskazać, że jeden ze wspólnoty przedkłada Bogu ofiarę, w którą zaangażowani zostali wszyscy uczestniczący. W tej sytuacji rola duchowieństwa otaczającego przewodniczacego nie może zostać ograniczona do asysty, która charakteryzuje raczej bierne zaangażowanie i co najwyżej pewną pomoc. Termin ten powinien być ograniczony wyłącznie do działań prystużników. Duchowni otaczający ołtarz, zgromadzeni po lewej i prawej stronach przewodniczacego, poprzez głoszone modlitwy i czynności liturgiczne, mogą być określeni jako ci, którzy wspótsprawuja. Z tego powodu siatka synonimów dotycząca czynności liturgicznej jednego duchownego może zostać wykorzystana również i tutaj.

Kolejnym synonimem określającym modlitewne zaangażowanie duchownych zgromadzonych wokół przewodniczącego jest termin wspótstużenie. Wspótstuga (gr.

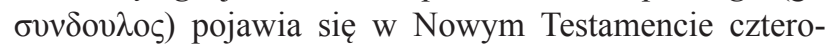
krotnie (Mt 18,29, Kol 4,7, Ap 19,10 i Ap 22,9). W Ewangelii Mateusza jest to określenie z przypowieści o dłużniku, w pozostałych biblijnych wystąpieniach termin ten odnosi się do apostołów bądź ich uczniów, którzy wypełniają Bożą wolę. Termin ten pojawia się również w prawosławnej terminologii liturgicznej, w „Obrzędzie świętego oleju”, w którym siedmiu prezbiterów sprawuje misterium uzdrowienia chorego: „nie kładę mej grzesznej ręki na głowie przychodzącego do Ciebie grzesznika, proszącego o odpuszczenie grzechów, ale Twoją rękę potężną i mocną, tę świętą Ewangelię, którą moi współsłudzy trzymają na głowie Twego sługi N. i modlę się z nimi, i proszę Twoją miłosierną oraz niepamiętającą zła miłość do ludzi, Boże..." (Euchologion. Tom 1, 2016, s. 208). Terminem tym określany jest również duchowny w obrzędzie pogrzebu: „Przeto prosimy Ciebie, Panie: słudze Twemu i naszemu współsłudze kapłanowi N., zmarłemu w nadziei zmartwychwstania życia wiecznego, daj odpoczynek na łonie Abrahama i Izaaka, i Jakuba" (Euchologion. Tom 1, 2016, s. 372). Biblijne i liturgiczne znaczenie tego terminu jest więc zbieżne i oznacza innych duchownych wspólnie modlących się z przewodniczacym.

Opierając się na dwuznaczności terminu celebracja, określenie soborowego sprawowania nabożeństwa może wykorzystać termin koncelebracja. Powinien on być jednak ograniczany i odsyłany do preferowanego terminu wspótsprawowanie.

Zdanie: „W Boskiej Liturgii sprawowanej przez biskupa Tomasza uczestniczył biskup Michał i dwunastu prezbiterów" możemy rozumieć jako nabożeństwo aktywnie prowadzone przez jednego biskupa. Funkcje i zadania drugiego biskupa i prezbiterów nie są tu określone. Kiedy zmodyfikujemy zdanie w kierunku ,....sprawowanej przez biskupa Tomasza wraz z biskupem Michałem i dwunastoma prezbiterami", mimo braku specjalistycznego terminu, przekaz jest już bardziej czytelny i wskazuje na zaangażowanie wszystkich wspomnianych duchownych. Kolejny wariant wykorzystuje opisane wyżej preferowane formy: „Boską Liturgię pod przewodnictwem biskupa Tomasza współsprawowali biskup Michał i dwunastu prezbiterów”. Ewentualnie „Boską Liturgię współsprawowali biskup Tomasz, biskup Michał i inni duchowni” lub „Boską Liturgię sprawowali biskup Tomasz, biskup Michał i inni duchowni”. W określeniu soborowego sprawowania nie powinniśmy wykorzystywać sformułowania „w asyście biskupa Michała”, „w asyście prezbiterów i diakonów” itp. Wspótsprawowanie, akcentujące zaangażowanie i obecność w prezbiterium wielu duchownych może być zastępowane określeniem sprawowanie.

\section{Glówne terminy i ich synonimy}

W oparciu o powyższą analizę spróbujmy uporządkować terminologię dotyczącą czynności liturgicznych prawosławnego duchownego tworząc siatkę synonimów i definiując główne artykuły hasłowe.

celebra $\rightarrow$ sprawowanie

celebracja $\rightarrow$ sprawowanie

celebrans $\rightarrow$ sprawujący.

celebrowanie $\rightarrow$ sprawowanie

koncelebra $\rightarrow$ współsprawowanie

koncelebracja $\rightarrow$ współsprawowanie

koncelebrans $\rightarrow$ współsprawujący

koncelebrant $\rightarrow$ współsprawujący

koncelebrowanie $\rightarrow$ współsprawowanie

koncelebrujący $\rightarrow$ współsprawujący

odprawianie $\rightarrow$ sprawowanie

przewodniczący lit. 'duchowny sprawujący nabożeństwo, w którym aktywnie uczestniczą inni duchowni’. Potaczenia: przewodniczący liturgii. Uwagi: nie należy używać jako synonimu wyrazu celebrans.

przewodniczenie lit. 'prowadzenie przez duchownego nabożeństwa, w którym aktywnie uczestniczą inni duchowni’. Polaczenia: przewodniczenie całonocnemu czuwaniu, przewodniczenie modlitwie, przewodniczenie nabożeństwu.

służący $\rightarrow$ sprawujący

slużenie $\rightarrow$ sprawowanie. Uwagi poprawnościowe: stużenie nabożeństwa nie stużenie nabożeństwu; stużenie stużby nie stużenie stużbie.

sprawowanie lit. 'prowadzenie przez duchownego nabożeństwa'. Połaczenia: sprawowanie akatystu, soborowe sprawowanie, sprawować nabożeństwo, sprawowanie panichidy za zmarłego, wspólne sprawowanie. Synonimy: pot. służenie, rzad. celebra, rzad. celebracja, rzad. celebrowanie, pot. odprawianie.

sprawujący lit. 'duchowny prowadzący nabożeństwo'. Potaczenia: sprawujący liturgię. Synonimy: pot. służący. wspólsłużący $\rightarrow$ współsprawujący 
wspólsłużenie $\rightarrow$ współsprawowanie

współsprawowanie lit. 'aktywne współuczestnictwo duchownych $\mathrm{w}$ sprawowanym przez przewodniczącego nabożeństwie'. Połaczenia: współsprawowanie liturgii, współsprawowanie misterium. Synonimy: pot. współsłużenie, rzad. koncelebra, rzad. koncelebracja, rzad. koncelebrowanie.

wspólsprawujący lit. 'duchowny aktywne współuczestniczący $\mathrm{w}$ sprawowanym przez przewodniczącego nabożeństwie'. Połaczenia: współsprawujący liturgię. Synonimy: pot. współsłużący, rzad. koncelebrans, rzad. koncelebrant, rzad. koncelebrujący.

\section{Zakończenie}

Prawosławna praktyka liturgiczna opiera się na fundamencie teologicznym i eklezjalnych zasadach. Funkcje liturgiczne duchownych opierają się na koncepcji przedstawionej w Piśmie Świętym, szczególnie w listach ap. Pawła. Wszystkie wskazane źródła unikają lub ograniczają jurydyczne analogie i wskazują przede wszystkim na funk- cję przewodniczenia, współdziałania, ofiarnej służby Bogu i ludziom. W takim ujęciu niewidoczne są funkcje urzę$\mathrm{du}$, administracji, władzy. Również kwestie autorytetu duchownych ukazane są bardziej przez pryzmat ich doświadczenia duchowego, świętości życia i udziale w łasce daru Świętego Ducha, a nie przez pryzmat uzyskanej władzy, czy godności urzędu.

Na przestrzeni wieków uwidacznia się to w terminologii prawosławnej, która nie podąża za kolejnymi kanonicznymi i teologicznymi uściśleniami teologii zachodniej. Prawosławie, zachowując świadomość daru łaski misterium kapłaństwa, powstrzymuje się przed rozwojem terminów określających czynności liturgiczne, i jak ukazuje to niniejszy artykuł, próbuje utrzymać określenia nawiązujące do posługi służebnej Bogu i ludziom. Stąd również w polskiej terminologii prawosławnej funkcjonuje szereg omówionych w tekście terminów, które podkreślają tę służebną rolę, a jednocześnie naturalnie różnicują i konkretyzują liturgiczne zadania duchownych. Zachowanie tych określeń tworzy naturalną spójność prawosławnej teologii, eklezjologii z praktycznym ich przejawem obserwowanym w życiu liturgicznym.

\section{Bibliografia}

Soborowa Komisja Redakcyjna, Pańkowski, J. (red.). (2011). Archijeratikon. (H. Paprocki, thum.). Warszawa: Warszawska Metropolia Prawosławna.

Boska Liturgia świętego ojca naszego Jana Chryzostoma. (2001). Warszawa: Warszawska Metropolia Prawosławna.

Stownik języka polskiego PWN. (2019). Wydawnictwo Naukowe PWN. [online] https://sjp.pwn.pl/, [14.04.2020].

Podręczna Encyklopedya Kościelna. t. 19 (1910). Warszawa: Gebethner i Wolff.

Besobrasoff, C. (1939). The Eucharist in the Orthodox Church. W: The Student World. (s. 105-114).

Bogacz, R. (2007). Dzieło zbawienia w ludzkiej krwi Jezusa wedlug Listu do Hebrajczyków, List do Hebrajczyków 3. Kraków.

Charkiewicz, J. (2018). Opracowanie listy źródeł „Słownika polskiej terminologii prawosławnej”. W: Elpis. 20 2018. s. 181186.

Golosov, G. (1886). Rukovodstvo po liturgike ili nauka o pravoslavnom bogosluženii. Tver': Tipo-litografiâ F. S. Murav'eva [Голосов, Г. (1886). Руководство по литургике или наука о православном богослужении. Тверь: Типо-литография Ф. С. Муравьева].

Gotc, R. (2014). Tainstva v istorii otnoshenij mezhdu Vostokom i Zapadom. Moskva: Svjato-Filaretovskij Institut [Готц, Р. (2014). Таинства в истории отношений между Востоком и Западом. Moskva: Свято-Филаретовский Институт].
Hasło: zhrecy, w: Jenciklopedicheskij slovar' Brokgauza i Efrona. (1894). Sankt-Peterburg. t. 23. s. 39 [Энциклопедический словарь Брокгауза и Ефрона. (1894). Санкт-Петербург. t. 23. s. 39].

Kern, K. (2006). Evharistiâ (iz čtenij v Pravoslavnom Bogoslovskom institute v Pariže). Moskva: Hram svv. bessr. Kosmy i Damiana na Marosejke [Керн, К. (2006). Евхаристия (из чтений в Православном Богословском институте в Париже). Москва: Храм свв. бесср. Космы и Дамиана на Маросейке].

Ławreszuk, M. (2014). Modlitwa wspólnoty. Historyczny rozwój prawosławnej tradycji liturgicznej. Białystok: Wydawnictwo Uniwersytetu w Białymstoku.

Ławreszuk, M. (2019). Baciuszka, prezbiter czy ksiądz? Poszukiwanie wiodącej denotacji w polskiej terminologii prawosławnej. W: Elpis, 21 2019, s. 15-19. https://doi.org/ 10.15290/elpis.2019.21.02.

Naegle, A. (1900). Die Eucharistielehre des hl. Joh. Chrysostomus. Strassburg.

Szyjewski, A. (2004). Religia Słowian. Kraków: Wydawnictwo WAM.

Vanhoye, A. (2015). Jezus Chrystus - kaptan nowego przymierza. [online] https://stacja7.pl/wiara/jezus-chrystus-kaplan-nowego-przymierza/, [2.03.2020].

Euchologion. Tom 1. (2016). J. Charkiewicz (red.). Warszawa: Wydawnictwo Warszawskiej Metropolii Prawosławnej. 